\title{
THE CORPORATE CHRIST: RE-ASSESSING THE JEWISH BACKGROUND
}

\author{
Andrew Perriman
}

\begin{abstract}
Summary
The corporate personality hypothesis is still a frequent recourse in Pauline scholarship. Despite some quite damaging criticism from Old Testament scholars it remains, in one form or another, a popular means of accounting for Paul's understanding of the relation of believers to the risen Christ. This essay undertakes a re-assessment of the empirical data for the hypothesis. It comes to the conclusion that Paul is unlikely to have had at hand in Judaism a conceptual model for the inclusion or incorporation of believers in Christ. The phenomena that have commonly been taken as evidence for the concept either have simply been misread or may be explained by reference to other less speculative aspects of Jewish thought and literary method.
\end{abstract}

\section{Introduction}

It has been for many years a quite common postulate of Pauline scholarship that his understanding of the relation between Christ and believers draws in some way or other upon a peculiarly Jewish conception of the group as a unified entity that finds expression or embodiment in a singular personality. Three aspects of Paul's thought in particular have been interpreted along these lines: the prepositional expressions 'in Christ' and 'with Christ' and associated phrases; the 'typological' relationship between Christ and Adam; and the description of the church as 'body (of Christ)'. The concept of 'corporate personality' has been subjected to sporadic but significant criticism which has led to a refinement of the categories employed, a repudiation of some of the more reckless and anachronistic arguments used in support of it, and to some extent an abandonment of the specific terminology. Nevertheless, the idea still persists that Paul thought of Christ as being more than individual, as in some real sense including believers in himself, and that ultimately this way of thinking had its origins in a Jewish understanding of the relation between the 
group and an outstanding individual figure. It appears, however, that an intriguing, but ultimately flawed, hypothesis has induced a consistent misreading of the texts. In this study, therefore, we will review and develop as concisely as possible the arguments-in particular the exegetical arguments-that have been put forward against the view that Judaism entertained a notion of corporate personality.

\section{Corporate personality and its critics}

H. Wheeler Robinson, who coined the phrase 'corporate personality' and whose work has provided the ground plan for the modern discussion of the theme, defines it in the first place in terms of the unity of a group which 'might function as a single individual through any one of those members conceived as representative of it'. This definition is elaborated through the description of four distinctive characteristics. First, the group remains a unity in its extension through time to include both its ancestors and its descendants: burial in the family grave, for example, is 'the realistic act which unites a man with his ancestors'. Secondly, corporate personality constitutes a thoroughly 'realistic' - and in the end psychologically groundedconception of the unity of the group and cannot be reduced to literary or idealistic categories. Thirdly, corporate personality is characterised by a 'fluidity of reference, facilitating rapid and unmarked transitions from the one to the many, and from the many to the one'. Finally, he argues that the group conception remained dominant even after the development of a new individualistic emphasis in Jewish religion under Jeremiah and Ezekiel. ${ }^{1}$

Robinson regards it as more or less self-evident that the notion of corporate personality provides an appropriate explanation of certain legal phenomena in the Old Testament. He summarily lists such instances as the destruction of Achan and his family (Jos. 7), the

1 H.W. Robinson, Corporate Personality in Ancient Israel (Philadelphia: Fortress, 1964), 1-9. Similar views had earlier been expressed by S. Mowinckel in his studies of the Psalms: see e.g. the discussion in J. de Fraine, Adam et son Lignage: Études sur la notion de "personnalité corporative» dans la Bible (Bruges: Desclée de Brouwer, 1959), 28. Note also J. Pedersen, Israel: Its Life and Culture I-II (London: OUP, 1926), 271, on the Achan incident. Among those who have since pursued the same line as Robinson: A.R. Johnson, The One and the Many in the Israelite Conception of God (Cardiff: University of Wales Press, 1961); B.J. LeFrois, 'Semitic Totality Thinking', $C B Q 17$ (1955), 195-203; de Fraine, Adam; G.W. Anderson, The History and Religion of Israel (Oxford: OUP, 1966), 15-16. 
execution of the seven sons of Saul to expiate for their father's slaying of the Gibeonites (2 Sa. 21:1-9), the practice of Levirate marriage (Dt. 25:5-10), the inculpation of a whole city for a murder in its vicinity (Dt. 13:12-18; 21:1-9), and the belief that Yahweh visits the iniquities of the fathers upon the children (Ex. 20:5). His main interest, however, is in certain less obvious areas of application. ${ }^{2}$ The idea is found, Robinson believes, in the prominence given to particular representative individuals in Israel's historical development and selfunderstanding, whether patriarch, priest, king or prophet. It appears in the oscillation between the singular and collective subject that is found in the Psalms, in narrative passages such as the speech of Israel to Edom in Numbers 20:19, or in the servant songs of Deutero-Isaiah. In such instances the need to choose between the individual and the collective interpretation is a modern dilemma: to the ancient mind the antithesis was a false one, for the conception of corporate personality readily accommodated the unmarked transition from one manner of reference to the other. Corporate personality has a bearing, moreover, on Hebrew morality, inasmuch as the values of kinship and community forged in Israel's nomadic, tribal past are assumed to have continued to shape the morality of the developed nation. In Robinson's view, however, the most familiar example of this representative function is 'the thoroughly Hebraic contrast of Adam and Christ made by the Apostle Paul, which draws all its cogency from the conception of corporate personality'.

The validity of the corporate personality hypothesis as an explanation of Pauline ideas has sometimes been questioned, but the arguments have for the most part been of a summary nature with no real consideration given to whether the concept is in the first place an accurate reflection of Old Testament thought. In fact, there appear to be rather strong grounds for distrusting the construction that Robinson and others have put upon these various phenomena.

In an important essay J.R. Porter has suggested that from the perspective of Hebrew law at least there are better ways of explaining the solidarity of the group than by the concept of corporate personality. He argues, first, that a distinction should be made 'between, on the one hand, the regular legal punishment for an individual, under the provisions of a recognised body of custom or law, and, on the other, the punitive consequences to others that may

2 Robinson, Corporate Personality, 10-19. 
result from a person's own $\sin ^{\text {' }}{ }^{3}$ It is only in this latter sense that it might be possible to talk about a common soul or personality. The example is given of the breaking of the taboo against eating during the battle of Michmash (1 Sa. 14). That the taboo was binding upon Jonathan even though he was unaware of it, and that the nation suffered the consequences of his action, could be explained by the postulate of corporate personality; but the purpose of the trial by lot was to establish the guilt of the individual apart from the nation. In fact, we might do better to attribute the inclusion of Jonathan to the strict and absolute nature of the oath pronounced by Saul (v. 24) than to any 'corporate' connection between Jonathan and the people. Secondly, where the group is involved in the sins of an individual, it is almost invariably in the case of 'crimes of an exceptional nature which fall outside the regular operation of the law'. Hebrew law as such, even in its earliest forms (e.g. the 'Book of the Covenant', Ex. 20-23), is concerned principally, if not solely, with the determination of individual responsibility. ${ }^{4}$ Thirdly, these exceptional instances can in any case be more adequately explained on the basis of other ideas, such as the 'quasiphysical' and 'contagious' nature of the holy, the view that the head of the household is owner of the family, or that the individual's name is perpetuated through his descendants. ${ }^{5}$

The reappraisal of corporate personality has subsequently been pursued in a different direction by J.W. Rogerson. Accepting Porter's conclusions with regard to the legal aspects of the doctrine, he seeks first to clarify the ambiguity in Robinson's use of the expression 'corporate personality' to denote both corporate responsibility and the supposed 'psychical unity' of the group, then proceeds to show how the anthropological theories upon which the psychological conception was based have since fallen into disrepute. In particular, the theory of Lévy-Bruhl, whose influence Robinson acknowledged, that primitive peoples are pre-logical, that their perception of the world fails to differentiate between objects, that they do not distinguish as we do between objective and subjective experiences, has been extensively

3 J.R. Porter, "The Legal Aspects of the Concept of "Corporate Personality" in the Old Testament', VT 15 (1965), 363.

4 J.R. Porter, 'Legal Aspects', 365-67. Cf. W. Eichrodt, Theology of the Old Testament I (ET; London: SCM, 1967), 240-41: Eichrodt argues that with the settlement of Israel in Canaan the sense of solidarity was transferred from the clan to the family, and that within this smaller group the value of the individual was enhanced.

5 J.R. Porter, 'Legal Aspects', 367-79. 
criticised. ${ }^{6}$ Not least, attention is drawn to the fact that Lévy-Bruhl tended to make generalisations about primitive cultures without regard either to negative evidence or to variations in social structure, a tendency which in Rogerson's view has also infected those who seek to apply the anthropologist's insights to Hebrew culture. While this in itself need not discount corporate personality as an explanation of certain Old Testament phenomena, ${ }^{7}$ it should lead scholars to reconsider some of the hazy presuppositions that may have prejudiced the interpretation of certain passages. As Rogerson concludes, 'The onus of proof rests on present-day exponents of corporate personality to show that their interpretation of Old Testament material would not be rejected by anthropologists if applied to material with which the latter are familiar.' 8

The force of these two studies ${ }^{9}$ has been registered by Pauline scholarship but this has not by any means led to a wholesale rejection of the hypothesis. A.J.M. Wedderburn, for example, has argued that 'the gravamen of Rogerson's criticism is directed not so much against the reality of the Old Testament data as against Robinson's evaluation and explanation of them'.${ }^{10} \mathrm{He}$ can still claim, therefore, that the most likely background to Paul's 'with Christ' language is 'the idea of Adam including all generations "in" himself" and the general pattern of representation that is found in the Old Testament." Similarly, J.D.G. Dunn accepts that the concept of corporate personality is 'another twentieth-century amalgam of disparate ideas', 12 but still maintains that the thought of Christ as the last Adam 'correlates with

6 J.W. Rogerson, 'The Hebrew Conception of Corporate Personality: A Reexamination', JTS 21 (1970), 9-10; see also J.W. Rogerson, Anthropology and the Old Testament (Oxford: Basil Blackwell, 1978), 54-55; cf. P. Joyce, 'The Individual and the Community', in J.W. Rogerson (ed.), Beginning Old Testament Study (London: SPCK, 1983), 77-79.

7 De Fraine accepts the general criticism of Lévy-Bruhl's theory of the absorption of the individual into the group, allowing only that traces of such primitive thought survive in sublimated form in the Old Testament (de Fraine, Adam, 29-37).

8 Rogerson, 'Hebrew Conception', 10.

9 See also e.g. G.E. Mendenhall, 'The Relation of the Individual to Political Society in Ancient Israel', in J.M. Myers (ed.), Biblical Studies in Memory of H.C. Alleman (Locust Valley: J.J. Augustine, 1960), 89-108; Joyce, 'The Individual and the Community'.

10 A.J.M. Wedderburn, Baptism and Resurrection: Studies in Pauline Theology against Its Graeco-Roman Background (Tübingen: J.C.B. Mohr [Paul Siebeck] 1987), 354; note also G.W. Grogan, 'The Old Testament Concept of Solidarity in Hebrews', TynB 49.1 (1998), 163-64.

11 Wedderburn, Baptism and Resurrection, 345.

12 J.D.G. Dunn, The Theology of Paul the Apostle (Grand Rapids, Michigan, Cambridge, UK: Eerdmans, 1998), 409, n. 89. 
the "in Christ" "mysticism" of Paul's soteriology, where Christ is envisaged as a corporate person "in" whom believers can find themselves' ${ }^{13}$ S.E. Porter, in an essay that is more interested in the methodological vagaries of New Testament scholarship than in the content of the corporate personality hypothesis, similarly recapitulates the criticisms made by J.R. Porter and Rogerson but points to the survival of the idea as a presupposition of Paul's thought. ${ }^{14}$ While there has been a tendency to downplay the influence of the Old Testament background and to modify the terminology ('psychical unity', 'corporate representation', etc.), the conviction remains that it forms an important and integral part of Jewish thinking. S.E. Porter's own distinctive contribution to the debate is to draw attention to a striking conceptual parallel in Sophocles' Oedipus the King. ${ }^{15}$ His argument in the end is less that corporate personality is a myth than that it is not confined to Judaism.

\section{Corporate personality in the Old Testament}

In view of this ambiguous state of affairs it is worth reconsidering, first, at least the more significant of the Old Testament narratives and ideas - and not only those of a legal nature - that have been taken as evidence for a way of thinking that is unable to distinguish clearly between the identity of the individual and the identity of the group. Are there, in fact, instances in which the transmission of effects between the one and the many is explicable only on the basis of a notion of the group, synchronically or diachronically conceived, as a psychically unified entity - such as might serve as a model for the idea of union with Christ? This must be recognised as a limited and provisional undertaking, both because the problem itself is extremely complex and because I approach it from the perspective of Pauline studies. Nevertheless, it seems necessary to give much closer attention than has generally been the case to those texts upon which the hypothesis has been founded.

\section{A. The principle of ownership}

One alternative explanation advanced for the solidarity of the group in the Old Testament is the principle of ownership. In respect of the

13 Dunn, Theology of Paul, 314.

14 S.E. Porter, 'Two Myths: Corporate Personality and Language/Mentality Determinism', SJT 43 (1990), 289-307.

15 S.E. Porter, 'Two Myths', 296-98. 
destruction of Dathan and Abiram along with wives and children and possessions (Nu. 16:23-33) J.R. Porter argues, first, that this was an exceptional punishment for an action (rebellion against Moses) that had put them outside the sphere of ordinary legal procedure, and secondly, that the households belonged to the two men not as an extension of their 'personalities' but as possessions that represented their strength in the contest with Moses. ${ }^{16}$ In other words, what determines the destruction of the household is not that it forms with the individual a corporate personality-or as Pedersen has it, a 'psychic community' consisting of a 'common will' and a 'common responsibility'17_but that it belongs to the individual.

In an extension of this principle Porter also holds that the judgment that came upon Israel after David numbered the people (2 Sa. 24:1017; cf. 1 Ch. 21:1-27) reflects not a conception of the people as being subsumed in the person of the kingl8 but the view that the king's prestige and strength is diminished if the nation of which he is headmuch as the father is head of the household - is weakened by famine, war or plague. ${ }^{19}$ Thus although the people suffer, the punishment is directed solely at the one responsible and there is no thought here of collective guilt. In this Porter follows D. Daube, who argued that the episode primarily illustrates the principle of 'ruler punishment' rather than of 'communal responsibility'. Daube points out that one of the penalties proposed for David was that he should flee for three months before his enemies (v. 13), which would not have inflicted anything like the same degree of suffering upon the people. ${ }^{20}$ Two further comments, however, are also appropriate. The first is that punishment comes upon the people because the Lord chooses to punish them, and equally can choose not to punish (v. 16). David protests that the people are innocent and prays that the hand of the Lord 'be against me and against my father's house', which suggests that he viewed the involvement of the people in the judgment as neither just nor inevitable. ${ }^{21}$ Secondly, the original cause of the judgment was not David's action but the sin of Israel: it was because 'the anger of the

16 J.R. Porter, 'Legal Aspects', 372-73. The expression 'you and all that are yours'

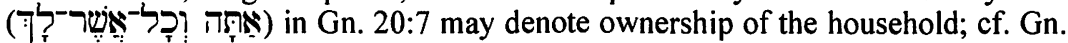
19:12; 45:10, 11; Dt. 8:13; 1 Sa. 25:6.

17 Pedersen, Israel, 271.

18 Cf. E. Best, One Body in Christ (London: SPCK, 1955), 208.

19 J.R. Porter, 'Legal Aspects', 373-74.

20 D. Daube, Studies in Biblical Law (Cambridge: CUP, 1947), 161; cf. W. Eichrodt, Theology of the Old Testament II (ET; London: SCM, 1967), 234.

21 Note Pedersen, Israel, 275-76. Cf. Moses' prayer in Nu. 16:22. 
Lord was kindled against Israel' that David was induced to order the census (24:1, RSV; cf. 1 Ch. 21:1). ${ }^{22}$ Although the reason for this anger is not made clear and the overriding emphasis in the story is on David's presumption, it at least appears that the offence was not David's alone. ${ }^{23}$

Something of an exception is the execution of the seven sons of Saul in 2 Samuel 21:1-9, a favourite passage with the proponents of corporate personality. ${ }^{24}$ Porter suggests that although it is the sons that suffer, technically the punishment is directed against Saul alone, inasmuch as the sons are part of his possessions and also keep his name alive. ${ }^{25}$ However, the text speaks of the death of the sons not as a punishment but, albeit figuratively, as an act of 'expiation' (cf. (פֵַַ) intended to bring about reconciliation (v. 3), chosen as such by the Gibeonites (vv. 5-6) ${ }^{26}$ It is a means of atoning for Saul's perfidiousness after the people of Israel had sworn to spare them. This entails a rationale quite different from the idea that they somehow participate in Saul's person.

It is significant, moreover, that this sort of solidarity emerges mostly in connection with sin and punishment. Only rarely is there an extension of salvation or blessing to the household and then it is probably better understood as part of the benefit or reward for the individual. Noah, for example, is saved with his family (Gn. 6:18), but it is implicit in the covenant with him that he should renew the race of men (cf. 9:1, 12). It is hardly surprising that Rahab asks that her 'father's house' be spared by the Israelites when they enter Jericho (Jos. 2:12-13; cf. 2 Ki. 10:30). De Fraine, in fact, has difficulty finding convincing examples of the extension of blessing from the individual to the group. ${ }^{27}$ What this suggests is that it is, in the first place, the nature of the deed that determines the extension of effects to the group rather than the corporate identity of the family. We should also bear in mind the degree to which the extension of liability to the family is countermanded in the Old Testament (Dt. 24:16; cf. $2 \mathrm{Ki}$. $14: 6) .28$

22 This observation explains why Daube still finds elements of communal responsibility determining the punishment of the people (Daube, Studies, 170).

23 See A.A. Anderson, 2 Samuel (Dallas: Word Books, 1989), 284.

24 E.g. Robinson, Corporate Personality, 2.

25 J.R. Porter, 'Legal Aspects', 377.

26 Against J.R. Porter, 'Legal Aspects', 377-78.

27 De Fraine, Adam, 58-64.

28 Cf. Eichrodt, Theology II, 240-241; R. de Vaux, Ancient Israel: Its Life and Institutions (London: Darton, Longman \& Todd, 1973), 23. 
Nor should we overlook the fact that very often there is real involvement of the group in the fate of the individual. When Jacob, in fear of attack from the Canaanites and Perizzites, says, 'I shall be destroyed, both I and my household' (Gn. 34:30), the point is not that 'when a man perishes, he also involves his house in his ruin', ${ }^{29}$ but that the whole household would naturally come under attack. Other passages have been similarly misinterpreted in terms of corporate personality when in fact they merely illustrate the conditions of tribal conflict (e.g. Judg. 12:1; 18:25). ${ }^{30}$ Real involvement of this sort is particularly likely in the case of idolatry. For example, Robinson cites the punishment of a whole city for heathenism (Dt. 13:12-18), ${ }^{31}$ but the assumption here is not that the many have been implicated in the sin of a few but that all the inhabitants have followed other gods (v. 13; cf. Dt. 13:6-11; Judg. 8:27; 1 Ki. 16:12-13).

\section{B. The contagion of holiness}

The celebrated incident with Achan (Jos. 7:10-26) presents the implication of the nation in the sin of one person ('Israel has sinned', v. 11), but there are strong reasons for doubting whether the inference of an extension of the person or of personality is justified. ${ }^{32}$

First, what is generally overlooked in those studies that regard this as illustrative of the principle of corporate personality is that the $\sin$ is attributed to Israel only as long as the individual culprit is unknown (vv. 11-12); once Achan is identified as the thief, only he and his family are punished. The purpose of the drawing of lots (vv. 16-18) is precisely to establish individual responsibility. 33 This, in fact, is a common circumstance. Abimelech complains to Isaac that 'one of the people might easily have lain with your wife, and you would have brought guilt upon us' (Gn. 26:10), ${ }^{34}$ but the problem of collective guilt arises only because the transgression is hypothetical and indeterminate. A city is held collectively responsible for a murder only when the murderer is unknown and some way must be found of

29 Pedersen, Israel, 272.

30 De Fraine, Adam, 53.

31 Robinson, Corporate Personality, 2.

32 Cf. Rogerson, 'Hebrew Conception', 4-5; Wedderburn, 'The Body of Christ and Related Concepts in 1 Corinthians', SJT 24.1 (1971), 83-85; the distinction is even made by Best (One Body, 207).

33 Against de Fraine, Adam, 72: 'Il s'agit manifestement d'une culpabilité collective'.

34 Cf. Wedderburn, 'Body of Christ', 84, n. 1. 
averting blood guilt (Dt. 21:1-9). ${ }^{35}$ The same is true with regard to Oedipus' crime, cited by S.E. Porter: 36 the city suffers while the offender remains unknown, but the outcome of the narrative is that the individual is punished.

Secondly, it is the presence of the devoted things among the people that is the ground for their implication in the sin of Achan (v. 13), not, as far as one can tell, any sense of collective identity. The transmission of effects appears to depend principally on the material and potent nature of the holy not on any conception of the group as a corporate entity. ${ }^{37}$ Admittedly, the whole family was destroyed along with Achan, but then so too were his possessions and livestock. Some other principle must be at work here than corporate personalityperhaps ownership, ${ }^{38}$ but more probably the 'contamination' of everything belonging to Achan, whether people or possessions, through contact either with the devoted objects or with Achan himself. ${ }^{39}$ That everything was burned-family and possessions alike-would appear to confirm this (v. 25). 40

In the same category should also be placed the story about the ark of the Lord in the house of Obed-edom in 2 Samuel 6:10-11. Contrary to E. Best's understanding, it is not said that blessing came upon the household of Obed-edom 'because the Ark of the Lord was left with him'. ${ }^{41}$ The household is blessed, as far as the text indicates, on account of the presence of the ark in the house, not of any particular relationship to Obed-edom, corporate or otherwise. But if, then, it is especially in relation to the presence of holy or devoted objects that a more inclusive punishment is inflicted or blessings shared among the household, it again appears that the process has more to do with the peculiar power of what affects the group than with any intrinsic corporate quality. Otherwise, the prescription of the law for a variety of offences, including blasphemy, murder, sorcery, incitement to

\footnotetext{
35 See Robinson, Corporate Personality, 2; J.R. Porter, 'Legal Aspects', 378-79.

36 S.E. Porter, 'Two Myths', 296-98.

37 Perhaps blood-guilt should be understood in the same way (e.g. 2 Sa. 3:29; 1 Ki. 2:5)

38 Cf. Joyce, 'The Individual and the Commnunity', 77.

39 Zeisler suggests that it may be 'a matter of ritual or moral pollution rather than anything more abstruse' (J. Zeisler, Pauline Christianity [Oxford: OUP, 1990], 62). Cf. J.R. Porter, 'Legal Aspects', 367-72; Eichrodt, Theology II, 241; R.J. Boling, Anchor Bible: Joshua (New York: Doubleday \& Company, 1982), 227-28; T.C. Butler, Joshua (Waco: Word Books, 1983), 86.

40 Note Eichrodt, Theology II, 423.

41 Best, One Body, 203, italics added.
} 
idolatry, filial stubbornness, and sexual immorality, is that the guilty person alone should be stoned. ${ }^{42}$

\section{Common ancestry and blood-ties}

The historical solidarity of the group in Israel with its ancestors and with future generations is unmistakable. The question is whether such a solidarity presupposes an underlying perception of the group as a corporate personality extended in time. Is not this sense of unity adequately explained by reference to such more tangible factors as common biological descent, blood-ties, shared historical and redemptive experience, and the natural socio-political cohesion of nomadic or semi-nomadic culture? The expression 'my bone and my flesh' (2 Sa. 19:12-13; cf. Judg. 9:2) points to an essentially physical or biological conception of the basis for solidarity.43 Burial in the family grave so as to be 'gathered to one's people' (Gn. 15:15; 25:8; 49:29; $\mathrm{Nu}$. 27:13) testifies to a strong sense of continuity, ${ }^{44}$ but the tribe is thereby thought of as a congregation, not as a corporate individual. The people of Israel are often spoken of as being the actual generation that was redeemed from slavery in Egypt (Lv. 25:42; Jos. $24: 6-8$; Am. $3: 1),{ }^{45}$ but on what basis would we want to attribute this to the idea of corporate personality rather than to a sense of national identity reinforced by descent and covenant? That the nation is

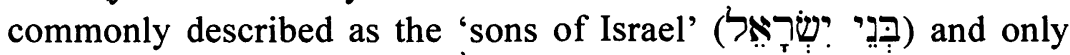

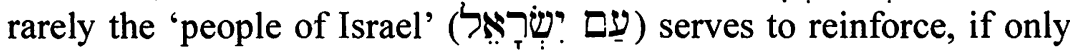
nominally, its genealogical identity. In those texts in which confession is offered for the sins of the fathers, it is generally apparent-and sometimes explicitly stated-that the current generation, at least until that moment, has been guilty of the same offence (e.g. Ezr. 9:7; cf. 2 Ki. 22:13; 2 Ch. 29:6-8; Ne. 9:2, 32-34). Jeremiah's confession of the iniquity of his ancestors (Je. 14:20) is hardly an unequivocal instance of corporate personality: 46 it is merely a recognition of the historical fact that the nation has been consistently depraved.

The practice of Levirate marriage has commonly been adduced as evidence for corporate personality, but the purpose behind the custom

42 E.g. Lv. 20:17; 24:23; Nu. 15:36; Dt. 13:5, 10;17:5; 21:21;22:21, 24; $1 \mathrm{Ki}$. $21: 13$. The destruction of the family is not specifically prescribed for the sacrifice of a child to Molech in Lv. 20:1-5, but if the man is not executed, the Lord himself will 'cut off' from among the people the man and his family.

43 Cf. de Vaux, Ancient Israel, 5.

44 Robinson, Corporate Personality, 3-4.

45 Cf. Wedderburn, 'Body of Christ', 83 and n. 5.

46 Against Best, One Body, 204. 
is clearly stated: 'the firstborn whom she bears shall succeed to the name of the deceased brother, so that his name may not be blotted out of Israel' (Dt. 25:6; cf. v. 7). At issue here is not any 'unitary group conception', as Robinson would have it, ${ }^{47}$ in which one member can act in the place of another with the same significance, but the 'survival' of the deceased brother through a son who adopts his name. The presupposition for the regulation need be only that the brother is already of the same family, not that the individual is subsumed within the collective identity of the group. While clearly there is a desire to defend the interests and unity of the family, the concern to perpetuate the name of the deceased, which is the avowed purpose of the custom, in fact differentiates the brothers. Porter concludes: 'Here indeed, as also with the obligation of blood-revenge, there is a very strong awareness of the solidarity of the family, but this is based on ties of kinship and the bond of property and does not require the postulate of "corporate personality" as this is understood by Wheeler Robinson, Pedersen or Johnson.' 48

\section{Covenant}

Not only biological descent but also covenant determines the proper basis for the perceived unity of the people of Israel with their forebears and descendants: God shows favour to Israel because of the covenant established with the patriarchs rather than because the group is included in the individual (cf. Rom. 11:28). When God is urged to 'remember thy servants, Abraham, Isaac, and Jacob' and to disregard the wickedness of the people (Dt. 9:27, RSV), nothing suggests, pace Best, ${ }^{49}$ that the soul of the patriarch was understood to survive and indeed expand in his descendants. Such a thought is certainly not contained in the idea of remembrance. While the sense of historical continuity is strong, the fundamental appeal is not to the nature of the people as a corporate personality but to the faithfulness and reputation of God who has committed himself covenantally to this people which he has redeemed (vv. 26, 28-29). The covenant is made not with Israel as a supra-historical corporate personality, as Robinson believes, ${ }^{50}$ but with a particular individual or generation (Abraham, Isaac, Jacob, Moses, the generation of the exodus): 'the Lord was gracious to them

47 Cf. Robinson, Corporate Personality, 2; Johnson, The One and the Many, 3.

48 J.R. Porter, 'Legal Aspects', 377. Porter also refers to the story of Ruth; cf. Pedersen, Israel, 254-57.

49 Best, One Body, 205, citing also Is. 41:8, 9; Ex. 32:13, 14.

50 Robinson, Corporate Personality, 26-27. 
and had compassion on them, and he turned toward them, because of his covenant with Abraham, Isaac, and Jacob, and would not destroy them' ( $2 \mathrm{Ki} .13: 23, \mathrm{RSV}) .^{51}$ The basis for the extension of its validity is, on the one hand, the faithfulness of God, and on the other, the historical and genealogical continuity of the nation. ${ }^{52}$ Beyond this there is no reason to think that we are dealing with anything more than a poetic conceit.

The expression about 'visiting the iniquities of the fathers upon the children to the third and the fourth generation of those who hate me' (Ex. 20:5; cf. 34:7; Lv. 26:39-40; Nu. 14:18; 18:1; Dt. 5:9), often cited as evidence for corporate personality, ${ }^{53}$ derives its significance specifically from its usage in the decalogue and occurs only in contexts in which the people, either through idolatry or disobedience, break faith with the God of the covenant. ${ }^{54}$ The reason is quite explicitly located in the character of God ('I the Lord your God am a jealous God') rather than in the nature of the Israelite family. The principal offence of those kings who were punished by means of the destruction of their houses (Jeroboam, Baasha, Ahab) was that they had worshipped other gods and thereby repudiated the covenant (e.g. $1 \mathrm{Ki} .13: 33-34 ; 14: 9-11 ; 16: 2-4 ; 21: 21-26)$. It may also be significant that when the story of Achan is alluded to in Joshua 22:20, the context indicates quite strongly that it is under the particular circumstances of rebellion against the Lord or breach of faith on the part of a minority or individual that the larger community is put at risk (22:16-19). Again it appears as a general rule that others are brought into the sphere of judgment only under certain circumstances, which makes us look to the nature of the crime rather than to the nature of the group for an explanation of the phenomenon.

51 This is true also for the passages in Jubilees cited in S. Kim, The Origins of Paul's Gospel (Grand Rapids: Eerdmans 1982), 190-91: Jub. 19:18, 29; 22:13.

52 The same applies for subsequent covenants, such as that with David (cf. 2 Ch. 21:7).

53 E.g. de Fraine, Adam, 89.

54 Robinson, Corporate Personality, 2. Porter suggests that 'the statement is to be interpreted as referring to the punishment of a father by the harming of his descendants who, on the one hand, are part of his possessions and, on the other, keep his name alive'. He interprets the punishment of the seven sons of Saul by the Gibeonites (2 Sa. 21:1-14) along the same lines (J.R. Porter, 'Legal Aspects', 37778). According to Durham the point is rather that in such cases the family is likely to have participated in the offence (J.I. Durham, Exodus [Waco: Word Books, 1987], 287). 


\section{E. Literary-religious factors}

One general consideration that is commonly overlooked in discussions of corporate personality is the fact that what we know about the thought-world of the ancient Israelites comes to us not in any neutral or objective form but for the most part filtered through the complex literary-religious mesh of the Old Testament, so that we cannot discount a certain literary reshaping and even distortion of the original perception. The question we should ask, therefore, is to what extent the various phenomena highlighted by proponents of corporate personality might be explained by reference to the context and manner of communication - as a matter, that is, of style, genre, convention, poetic technique, religious purpose, etc.

So, for example, while the oscillation between singular and plural forms of address in legal prescriptions is remarkable (e.g. Ex. 13:3-12; $20: 23-24 ; 22: 21-24 ; 23: 9), 55$ it could just as well be argued-though no more easily proved - that the confusion is not anthropological or psychological but of a linguistic nature, arising at the level of reference, as attention switches fluidly and for the most part inconsequentially between the group and the individual. The very fact that this trait is especially associated with legal texts might also suggest that a formal explanation is required. In certain instances, the alternation appears to indicate no more than a shift from a general to a particular perspective. So the entry of the people into Canaan is seen as a collective undertaking (cf. Dt. 11:8-32), but it is each individual who will have responsibility for cultivating the land (Lv. 25:2-3; cf. vv. 13-14).56 It could be argued, too, that the alternation between the singular and plural in the Psalms has more to do with the corporate character of worship than with any more far-reaching sense of corporate personality. ${ }^{57}$ Liturgical-poetic texts of this sort do not, in any case, constitute a sound basis for such a theory of selfunderstanding. At times, however, the referential confusion is simply not apparent: nothing in Psalm 22, for example, indicates that the psalmist is identified with the whole nation. 58

55 Cf. de Fraine, Adam, 108-112; Grogan, 'Old Testament Concept', 164.

56 But note de Fraine, Adam, 111-12.

57 Note Rogerson, 'Hebrew Conception', 14-15. According to Craigie the alternation between singular and plural in Ps. 44 may be merely a literary convention but more probably reflects an alternation of speakers (P.C. Craigie, Psalms 1-50 [Waco: Word Publishing, 1983], 331-32).

58 Against H.W. Robinson, The Cross in the Old Testament (London: SCM, 1955), 78. The strong bulls of Bashan are merely a figure for the irreligious who mock the psalmist (v. 12). 
Johnson cites instances where a personal attribute such as the soul

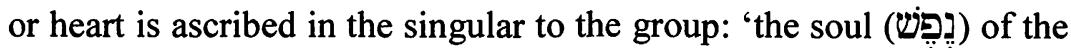
people became impatient...our soul hates this light bread' (Nu. 21:45); 'our soul withers' (Nu. 11:6). ${ }^{59}$ But again other more plausible explanations present themselves. The anomaly may, in fact, be no more than an accident of language: 'head' (ראש (רא) is frequently used in the singular with reference to a group with no suggestion that a collective body is in view (e.g. Jos. 7:6; Is. 35:10; Ezk. 1:25). However, the impression is also given that the idiom signifies in a quite natural manner a shared experience or disposition-without invoking the hypothesis of a corporate psyche. Where the plural occurs, the emphasis is by contrast on the actions of the individuals that constitute the group (e.g. Ex. 30:15-16). When Jehu says to the military council, 'If it is in your (plural) mind...' ( $2 \mathrm{Ki} .9: 15)$, there is no reason to think that he means the corporate identity of the group rather than simply their agreed purpose. ${ }^{60} \mathrm{~A}$ further possibility is that in some contexts the singular form of words such as 'soul' or 'heart' has the effect of connoting, in the absence of a more abstract terminology, such general notions as 'life' (e.g. Jos. 2:14) or 'attitude' or 'intention' (e.g. Jos. 5:1). At least, therefore, before attributing expressions of this sort to a realistic collective consciousness, we should consider whether they are not merely idiomatic or a matter of linguistic accident.

The use of the first person singular pronoun in the speech of the 'people of Israel' to the king of Edom (Edom is Esau, the brother of Jacob: Gn. 25:30) in Numbers 20:19 may only reflect the formal identification of a nation in terms of its ancestor and in particular the rhetorical figure established by Moses in v. 14 with the words, 'Thus says your brother Israel...' 61 The importance of the figurative context is also suggested by the fact that it is only very rarely that Edom is personified or 'individualised' in this way (perhaps Ezk. 25:12; Am. 1:11); generally the reference is in a quite straightforward manner to the land or the nation. While it would be difficult to settle the matter one way or the other, we might also consider, more broadly, whether

59 Johnson, The One and the Many, 8, citing also Gn. 23:8; Is. 3:9; Ps. 124:7.

60 Cf. Gn. 23:8; Is. 46:2; 66:3, where the singular form of נֶּפש need only signify a common intention or mind.

61 See Johnson, The One and the Many, 11-12. When the Lord says to Rebekah, 'Two nations are in your womb' (Gn. 25:23) we may read this as a poetic identification of Edom and Israel with their ancestors (note Grogan, 'Old Testament Concept', 163), but the point of the statement is only that these two sons will be the fathers of two nations whose histories will be closely intertwined. 
this sort of conception of Israel as an individual reflects a real perception or is to be explained as a narrative technique. Does it, for example, have something to do with the way in which dealings between peoples-conflicts in particular-are conventionally narrated (e.g. Nu. 21:1-3, 21-24; cf. Ex. 17:8-13)? Is it principally a stylistic characteristic of the conquest narratives in Numbers? Naturally, these considerations go well beyond the purview of this essay, but we should at least insist that any inference made about the 'psychic' or 'psychological' nature of such an identification of the people with the patriarch must take account of the literary context. If the context tends stylistically to isolate the 'figure', as, for example, the oracular form of Amos 1:11-12 isolates the allusion to Edom pursuing his brother with a sword, then it probably cannot simply be taken as representative of general thought.

Robinson says that we should not 'think of a merely ideal or figurative existence of Rachel, when the prophet depicts her as weeping for her children by the family graves; Rachel weeps because she dies in her children. ${ }^{62}$ But while this verse (Je. 31:15) may be evidence for a strong sense of historical continuity, to suggest that Rachel is here conceived of as having a real existence is surely to misunderstand the literary character of the passage. It is God who refers to Rachel weeping for her children, assuring her that they will return. In the same speech Ephraim, Rachel's grandson but claimed by Jacob (Gn. 48:5), professes penitence and a desire to return (vv. 1819). Why should this not be regarded simply as poetic dramatisation? ${ }^{63}$ Likewise, the narration of Israel's history as the history of an unchaste woman in Ezekiel 16 and 23 would no doubt take on a deeper meaning, as Robinson argues, 'in the light of such considerations' about the realism of the idea of corporate personality; but altogether absent is the opposite argument, that Israel must be thought of quite realistically as a corporate personality in the light of these and other texts. ${ }^{64}$ Otherwise, there seems no reason not to regard such passages as poetic representations of the relation between God and his people.

62 Robinson, Corporate Personality, 6. See also Robinson, The Cross, 65-114; de Fraine, Adam, 158-71.

63 Cf. J.A. Thompson, The Book of Jeremiah (Grand Rapids: Eerdmans, 1980), 573.

64 Robinson, Corporate Personality, 5. See also e.g. Nu. 11:12; Dt. 8:2-20; Is. 1:56; 54; Ho. 11:1. 
Robinson also argues rather unconvincingly that the thought of corporate personality 'throws light on the peculiar prominence of individual personalities both in the making of Hebrew history and in the development of Hebrew religion' ${ }^{65}$ Both the king and the nation are described as Yahweh's son (2 Sa. 7:14 and Ho. 11:1), but the terminological coincidence signifies not an identification of the two objects but a similarity of relationship and function. The high priest Joshua represents the community in Zechariah 3:1-10, but the context is visionary and the identification of Joshua and the people symbolic rather than real. Nehemiah identifies himself with the people who have sinned (Ne. 1:6), but Robinson does not bother to consider whether this might not be adequately explained as a moral rather than a psychic or psychological identification. No basis is given for the assertion that the 'profound sympathy' the prophet has for the people (e.g. Je. 8:21) 'owes not a little to this corporate identity'. The suggestion that 'Gomer in both her sin and her anticipated repentance is the nation of which she is an actual sample and an epitomising and representative unit' is simply nonsensical: an individual is, of course, an 'actual sample' and may epitomise and represent the group to which she belongs, but this does not amount to a realistic identification.

In Robinson's view the difficulty that scholars have had in identifying the servant figure of Deutero-Isaiah is evidence that the whole debate has been conducted on the grounds of 'an antithesis true to modern, but false to ancient modes of thought' ${ }^{66}$ In the light of the Hebrew conception of corporate personality 'the Servant can be both the prophet himself as representative of the nation, and the nation whose proper mission is actually being fulfilled only by the prophet and that group of followers who may share his views'. Robinson seems close to contradicting himself here by the admission that the conception of the nation as servant in practice reverts back to the prophet and his circle. Otherwise, we need only comment that Old Testament scholars have by no means unanimously endorsed the corporate personality interpretation of the songs. ${ }^{67} \mathrm{~J} . \mathrm{L}$. McKenzie is one who makes use of the corporate personality interpretation, accepting Robinson's basic argument that it 'resolves the tension

65 Robinson, Corporate Personality, 10-11.

66 Robinson, Corporate Personality, 15.

67 Von Rad, for example, allows that the 'boundaries between the two ideas are fluid' but then only 'at certain points' (G. von Rad, Old Testament Theology II [ET; London: SCM, 1965], 260). 
between the individual and the collective traits' ${ }^{68} \mathrm{But}$ he is able to do so only by treating the Servant as an ideal individual, who 'reflects the genuine character of all Israel' and is an 'incorporation of Israel' but is himself 'metahistorical'. In the end, therefore, if the only real reference is to Israel, it is difficult to see how this differs from personification: the Servant is only a figure for 'Israel which perseveres'.

Finally, the representation of the 'saints of the Most High' as 'one like a son of man' (Dn. 7:13-27) undoubtedly says something about the collective identity of the people which cannot be reduced to the terms of a social contract. ${ }^{69}$ But there is no basis for thinking that anything more is intended with regard to the solidarity or unity of the people than is already inherent in their existence as a covenant nation. ${ }^{70}$ In view both of the general character of the apocalyptic vision and of the explicit 'interpretation' of the various figures in verses $16-18$, it seems fully appropriate to treat the identification as symbolic. In any case, the significance of the 'one like a son of man' is not so much that he is an individual but that he is in human form in contrast to the four beasts of the preceding visions. The singularity of the 'one like a son of man' is determined not by his relation to the people but by the general pattern of symbolic representation that operates in the passage, according to which the four beasts represent four kingdoms (vv. 17 [LXX], 23). In the context of the vision the 'one like a son of man' is no more 'real' as an individual figure than the four great beasts. It is significant, in this respect, that in the interpretation of the vision, although the Hebrew text speaks of the beasts as four 'kings' (v. 17) and considerable attention is given to the last king who 'shall be different from the former ones' (v. 24), no king is attributed to the 'saints of the Most High', on whom collectively sovereignty is directly bestowed.

68 J.L. McKenzie, Second Isaiah (New York: Doubleday \& Company, 1967), liii. See also H.H. Rowley, The Servant of the Lord (Oxford: Basil Blackwell, 1964), 360 .

69 Robinson, Corporate Personality, 5-6; cf. de Fraine, Adam, 172-78.

70 See further Kim, Origins, 248-49, 254; Best, One Body, 210. In later apocalyptic literature the 'son of man' figure is interpreted only as an individual, not as the nation (see references in J. Jeremias, New Testament Theology [ET London: SCM, 1971], 269). On the interpretation of the 'humanlike figure' see J.E. Goldingay, Daniel (Dallas: Word Publishing, 1989), 169-72. 


\section{Corporate personality in other Jewish writings}

Arguments from non-biblical Jewish literature have to do principally with speculation about Adam. E. Schweizer's view that Judaism conceived of the progenitor ('Stammvater') as one who is identical with and who determines the destiny of a people or tribe has been influential but is less self-evident than he and others have supposed. Wisdom 10:1ff. does not, for example, speak only of Adam when the histories of Cain, Noah, Abraham, Joseph, etc., are recounted.71 Although these various figures are not named, being designated instead either as 'the unrighteous one' or 'the righteous one', there is no reason to think that they are undifferentiated or subsumed under the 'first-formed father of the world' (10:1): they variously illustrate how men, principally the righteous, are saved by Wisdom (9:18). The significance of the descent of the twelve tribes from one father in 2 Baruch 78:4 is not that they are one or united but that all the tribes should, symbolically at least, share the same destiny. Schweizer appears to have misread the passage, which does not say that all the tribes went into captivity, but that all, including the two and a half tribes that did not go 'across the river' $(78: 1)$, were 'bound by one captivity'. ${ }^{72}$ The point is not that all the tribes are one but that they are all captive. In Apocalypse of Abraham 23:10 it is not certain that mankind is called Adam: on the one hand, the translation is doubtful; 73 on the other, the statement belongs to what is clearly an allegorical interpretation of the vision of Adam, Eve and the serpent. Likewise, although mankind is referred to as Adam in Testament of Simeon 6:5, it is arguable that this and the reference to Shem in the same verse are only a literary extension of the eponymous naming of the tribes of Israel.

While Jacob is sometimes depicted, notably in Philo, as a heavenly figure closely associated with the Logos and the heavenly Adam ${ }^{74}$ and as the head of a chosen people, we can be less confident that in Jubilees, which does not have the idea of Jacob as a heavenly figure, the historical relationship between the ancestor and his seed gives way to one of identification ('the ancestor is largely identical with his

\footnotetext{
71 E. Schweizer, 'Die Kirche als Leib Christi in den paulinischen Homologumena', Theologische Literaturzeitung 86.3 (1961), 164.

72 J.H. Charlesworth, The Old Testament Pseudepigrapha I (London: Darton, Longman \& Todd, 1985), 648.

73 See Charlesworth, Pseudepigrapha I, 700, note i.

74 Schweizer, 'Die Kirche', 167.
} 
tribe'). ${ }^{75}$ It is important to recognise that the apparent continuation of Jacob in his seed is closely associated with the extension of blessing (Jub. 19:20-24, 27; 22:13). It is this principally which provides the rationale for the identification of the tribe with its ancestor, but it must be understood, surely, in light of the fact that there was no prospect of continuation in resurrection. Jubilees in particular has little interest in an eschatological future, and the death of Jacob is presented in fully conventional terms (45:13-15). ${ }^{76}$

R. Jewett has argued that behind Paul's description of the church as the body of Christ lies Jewish speculation about the 'guf-Adam'-not as an 'exact parallel' but at least as a 'definite analogy'. But this argument suffers not only from the fact that such an influence is historically improbable but also from certain interpretative distortions. ${ }^{77}$ First, the tradition about Adam's gigantic golem ('unformed mass') recorded in Exodus Rabbah 40.3 (cf. Tanhuma ki Tissa 12; Gen. R. 24.2; Aboda Zara 5a) does not depict his descendants as being 'included' in him. God reveals to Adam in a vision the righteous who would descend from him, and whose names are written in the book of Adam, hanging on the various parts of his as yet unformed body or, according to Pesikta Rabbati 23.1, in a parade passing before Adam. At most this points to a belief that they had their origin in Adam; it says nothing about a present relationship between Adam and his descendants, as Jewett admits. ${ }^{78}$ Secondly, the idea that a predetermined number of souls are stored in the guf of Adam's body is also doubtful. In certain of the texts mentioned by Jewett the pre-existent souls are simply listed in the book of Adam (Gen. R. 24.4; Lev. R. 15.1). ${ }^{79}$ Where there is reference to the souls contained in a guf (Yeb. 62a, 63b; Aboda Zara 5a; Nidda 13a), it is doubtful that this is equated with Adam's body; Jewett himself provides no evidence for the assumption. The rabbis did not interpret the guf in this way. According to the traditional view the word denotes a 'promptuary' (repository), but it has also been identified with the

75 Schweizer, 'Die Kirche', 168; cf. Kim, Origins, 190-91.

76 Cf. Charlesworth, Pseudepigrapha II, 46-47.

77 R. Jewett, Paul's Anthropological Terms: A Study of Their Use in Conflict Settings (Leiden: E.J. Brill), 242-44; also Kim, Origins, 254.

78 Jewett, Paul's Anthropological Terms, 245.

79 Davies argues that the revelation to Adam of the generations to come 'really means that all subsequent generations were in him as it were' (W.D. Davies, Paul and Rabbinic Judaism [London: SPCK, 1955], 54). But it is in the intention of God, not in the body of Adam, that these souls pre-exist: 'The royal Messiah will not come until all the souls which [God] contemplated creating have been created' (Gen. R. 24.4; cf. Aboth R.N. 29a [3]). 
curtain before God's throne, on which all souls are painted. ${ }^{80}$ Hebrew Enoch 43:3 speaks of the creation of the souls of the righteous 'in the storehouse ( $\mathrm{guf}$ ) of beings' (Alexander), but no connection is made with Adam. Since there is also mention of 'the souls of the righteous which have not yet been created in the storehouse', it seems unwise to interpret the $g u f$ as being the container for all Adam's descendants. The 'Mighty Prince' whose body fills the space between earth and the seventh heaven and on whose face is the Shekinah (22:2-6) has no connection either with Adam or the souls of the unborn; this angelic figure is Kerubi'el YHWH, who is in charge of the cherubim. The texts cited by Jewett, therefore, offer very little support for the conception of Adam as a gigantic body in whom individual souls are included.

The idea is found in Rabbinic literature that in some way or other the creation of Adam had global proportions, perhaps suggesting the essential unity of mankind. A statement attributed to R. Meir reads: 'The dust of the first man was gathered from all the parts of the earth...' (b. Sanh. 38a). A later tradition asserts: 'Adam's trunk came from Babylon, his head from Erets Yisrael, his limbs from other lands, and his private parts, according to R. Aha, from Aqra di Agma' ( $b$. Sanh. 38a). There is also the opinion of R. Tanhuma that God created Adam 'as a lifeless mass extending from one end of the world to the other' (Gen. R. 8.1). To infer from these passages, however, as W.D. Davies does, that all mankind was included in the body of Adam in a manner analogous to the being of Christians in Christ is untenable. There is no 'natural' line of development between this symbolic expression of universalism and the supposedly Pauline idea of a new humanity "incorporated "in Christ"' .81

N.T. Wright has also recently overstated the extent to which Judaism depicts the future restoration in Adamic terms. ${ }^{82}$ Creation motifs such as being fruitful and multiplying (e.g. Gn. 35:11-12; Je. 3:16), Sabbath observance (Jub. 2:23), covering of nakedness (Jub. $3: 30-31$ ), have more to do with the continuation of something begun at creation than with the restoration of a true humanity. The subjugation of 'beasts' in apocalyptic writing (e.g. Dn. 7; 1 En. 90:19,

80 L. Ginzberg, The Legends of the Jews V (Philadelphia: The Jewish Publication Society of America, 1925), 75, n. 19; also Charlesworth, Pseudepigrapha I, 294, note i.

81 Davies, Paul and Rabbinic Judaism, 57.

82 N.T. Wright, The Climax of the Covenant: Christ and the Law in Pauline Theology (Edinburgh: T. \& T. Clark, 1991), 18-26. 
30, 37-38) hardly corresponds to Adam's stewardship of the creatures in the garden. The priest in Testament of Levi 18:10-11 will open the gates of paradise and remove the sword so that the saints may eat of the tree of life, but there is no depiction of Israel as restored Adam; Israel, in fact, stands under judgment (v. 9). If according to 4 Ezra and 2 Baruch Israel is given 'the rights of Adam's true heir', 83 this does not entail the thought that in Israel Adam is restored. In the Qumran texts the righteous will inherit 'all the glory of Adam' (e.g. 1QS 4.23), but this does not express the thought of inclusion in a restored Adam; and Paul certainly does not mean that Christ has recovered the glory of Adam.

The vicarious sufferings of the Maccabean martyrs, cited by E. Best in an appendix to One Body in Christ, ${ }^{84}$ testify to the solidarity of the group but are to be explained in terms not of corporate personality but of the sacrificial system: 'they having become, as it were, a ransom

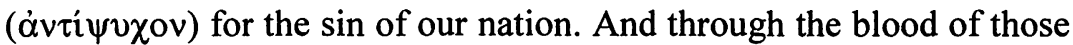

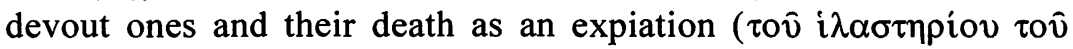

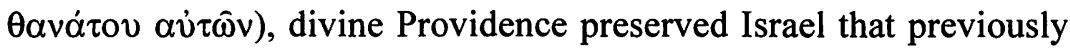
had been afflicted' (4 Macc. 17:21-22, RSV; cf. 4 Macc. 6:28-29; 2 Macc. 7:37-38). Here the point is precisely that the one 'sacrificed' is set apart from the group and killed instead of it.

Finally, none of the Rabbinic texts mentioned by Best entails anything like a merging of identity between the one and the many .85 The most that is presupposed is the historical continuity of the people with the righteous patriarchs, on the basis of which the nation is redeemed. If in the Passover liturgy every Jew is exhorted to 'regard himself as though he himself had gone forth from Egypt', there is no reason to believe that this was meant as anything other than a liturgical fiction underlying the real, if less concrete, sense of salvation in the present: 'He has brought us forth from bondage to freedom, from sorrow to joy, from mourning to festival, from darkness to bright light, and from slavery to redemption. ${ }^{86}$ The quotation from $M$. Sanhedrin 4.5 illustrates not so much the solidarity of the human race as the value attached to the individual life: 'For this reason a single man only was created, to teach you that if one destroys a single person, the Scripture imputes it to him as though he had

\footnotetext{
83 Wright, The Climax of the Covenant, 24.

84 Cf. Best, One Body, 205.

85 Best, One Body, 205-206.

86 See Davies, Paul and Rabbinic Judaism, 103, emphasis omitted from Davies' citation.
} 
destroyed the whole world, and if he saves the life of a single person, the Scripture imputes it to him as though he had saved the whole world.'

\section{Conclusions}

The scope of this essay has been limited. The principal aim has been to question the persistent assumption among many writers on Paul that he could have found in Jewish literature a conception of the incorporation or inclusion of a group in a prominent individual that might have served as a model for his own understanding of the relation of believers to Christ. The method of enquiry has been simply to re-examine those texts that have commonly, and often uncritically, been thought to illustrate this conception. The results of this study might be better collated and made the basis for a more systematic understanding of the complex interaction between individual and community in Jewish thought. ${ }^{87}$ There is also the question of whether Paul might have developed a corporate conception of Christ quite apart from any specific Jewish antecedent. These matters cannot be addressed here. For now we must confine ourselves to the essentially negative observation that the undoubtedly strong sense of solidarity that is found in these texts does not require the premise of the incorporation of the group in an individual. Either the texts have been misread or the notion of corporate personality has appeared as a redundant fiction and it has been possible to account for the phenomena on other grounds. Despite the important representative and symbolic function that certain individuals have in Jewish thought, in the end, we are left with very little that might account for the idea that believers are somehow spatially or psychically located in Christ or in the body of Christ.

87 Cf. Joyce, 'The Individual and the Community'. 